\title{
THE ORIGIN OF THE NAME «METATRON» AND THE TEXT OF 2 (SLAVONIC) ENOCH
}

The history of scholarship on 2 Slavonic Apocalypse of Enoch has produced no real consensus concerning the possible provenience of this apocalypse. ${ }^{2}$ Rather, there are numerous scholarly positions. ${ }^{3}$ These conclusions

${ }^{1}$ This study has benefited considerably from the comments and kindnesses of the following scholars who read the MS and preliminary materials at various stages: Christfried Böttrich, James Charlesworth, John Collins, April De Conick, Ian Fair, Everett Ferguson, Daniel Matt, André Resner, E. P. Sanders, Alan Segal, Carolyn Thompson, James Thompson, James VanderKam, Ben Zion Wacholder.

${ }^{2}$ F. I. Andersen in his English translation of 2 Enoch notes that «there must be something very peculiar about a work when one scholar concludes that it was written by a hellenized Jew in Alexandria in the first century BCE while another argues that it was written by a Christian monk in Byzantium in the ninth century CE». See F. I. ANDERSEN, 2 (Slavonic Apocalypse of) Enoch // OTP. Vol. 1. 95.

${ }^{3}$ See Andersen, 2 Enoch...; F. Borsch, The Son of Man in Myth and History (Philadelphia, 1967); C. BöттRICH, Das slavische Henochbuch (Gütersloh, 1995) (JSHRZ, 5); IDEM, Weltweisheit, Menschheitsethik, Urkult: Studien zum slavischen Henochbuch (Tübingen, 1992) (WUNT, 2/50); C. BurkitT, Jewish and Christian Apocalypses (London, 1914); R. H. Charles, The Date and Place of Writings of the Slavonic Enoch // JTS 22 (1921) 163; J. H. Charlesworth, The Pseudepigrapha and Modern Research (Missoula, MT, 1976); J. Collins, The Genre Apocalypse in Hellenistic Judaism // Apocalypticism in the Mediterranean World and the Near East / Ed. D. Hellholm (Tübingen, 1983); L. Gry, Quelques noms d'anges ou d'êtres mystérieux en II Hénoch // RB 49 (1940) 195-203; J. DANIÉLOU, The Theology of Jewish Christianity (Chicago, 1964); J. Fossum, Colossians 1.15-18a in the Light of Jewish Mysticism and Gnosticism // NTS 35 (1989) 183-201; K. LaKE, The Date of the Slavonic Enoch // HTR 16 (1923) 397-398; M. MCNAMARA, Intertestamental Literature (Wilmington, DE, 1983); Н. А. МЕщЕРский, Следы памятников Кумрана в старославянской и древнерусской литературе (К изучению славянских версий книги Еноха // Труды отдела древнерусской литературы 19 (1963) 130-147; он жЕ, К истории текста славянской книги Еноха (Следы памятников Кумрана в византийской и старославянской литературе // BB 24 (1964) 91-108; ОН жЕ, К вопросу об источниках славянской книги Еноха // Краткие сообщения Института народов Азии 86 (1965) 72-78; J. T. MiLiк, The Books of Enoch: Aramaic Fragments of Qumran Cave 4 (Oxford, 1976); G. W. E. NicKelsburG, The Books of Enoch in Recent Research // RSR 7 (1981) 210-217; H. Odeberg, 3 Enoch or the Hebrew Book of Enoch (New York, 1973); M. Philonenko, La cosmogonie du «Livre des secrets d'Hénoch // Religions en Égypte: Hellénistique et romaine (Paris, 1969); S. PINES, Eschatology and the Concept of Time in the Slavonic Book of Enoch // Types of 
are most likely the consequences of the different backgrounds and perspectives which scholars have brought to their study of 2 Enoch.

One of the important insights of research on 2 Enoch is the view that the text has deep connections with so-called Merkabah mysticism. ${ }^{4}$ Among the

Redemption / Ed. R. J. Zwi Werblowsky, J. Jouco BleEKer (Leiden, 1970) (SHR, 18) 72-87; H. H. Rowley (ed.), A Companion to the Bible (Edinburgh, 1963); A. RubinSTEIN, Observations on the Slavonic Book of Enoch // JJS 15 (1962) 1-21; G. ScHOLEM, Major Trends in Jewish Mysticism (New York, 1954); IDEM, Origins of the Kabbalah (Princeton, 1987); M. E. Stone, Jewish Writings of the Second Temple Period (Assen-Philadelphia, 1984) (CRINT, 2.2) 2.406-408; A. VAILLANT, Le livre des secrets d'Hénoch: Texte slave et traduction française (Paris, 1952; repr. Paris, 1976); H. WICKS, The Doctrine of God in the Jewish Apocryphal and Apocalyptic Literature (New York, 1971).

${ }^{4}$ The term «Merkabah» is closely connected with the term which designates the mystical interpretation («Mac ase Merkabah» — «The Account of the Chariot» or «The Works of the Divine Chariot») of the first chapter of Ezekiel. Earliest traces of the Merkabah tradition are situated in apocalyptic and Qumran literature. However, as Gruenwald notes, the main corpus of the Merkabah literature was composed in Israel in the period 200-700 CE. Some references to this tradition can be found also in the literature of German Hasidim (twelfth to thirteenth centuries CE) and medieval Kabbalistic writings (the Zohar).

The term «Hekhalot» («Divine Palaces») designates the corpus of literature that first gives a full-scale presentation of Merkabah mysticism (the beginning of the tradition is connected with the circle of Rabbi Yohanan ben Zakkai and his pupils). According to Gruenwald the main subjects dealt with in the Hekhaloth literature are heavenly ascensions and the revelation of cosmological secrets. I. GRUENWALD, Apocalyptic and Merkavah Mysticism (Leiden, 1980) (AGAJU, 14). The term «Merkabah» (the «Chariot») can be used also in its technical Kabbalistic meaning as the link between the physical and the divine worlds or as one of the upper worlds. On the Merkabah and the Hekhaloth traditions, see the following sources: D. BLuMENTHAL, Understanding Jewish Mysticism: A Source Reader: The Merkabah Tradition and the Zoharic Tradition. 2 vols (New York, 1978); I. CHERnUs, Mysticism in Rabbinic Judaism (Berlin, 1982) (SJ, 11); M. CoHEN, The Shicur Qomah: Liturgy and Theurgy in PreKabbalistic Jewish Mysticism (Lanham, 1983); I. Gruenwald, M. SMith, The Hekhaloth Literature in English (Chico, CA, 1983); D. HALPERIN, The Faces of the Chariot: Early Jewish Responses to Ezekiel's Vision (Tübingen, 1988) (TSAJ, 16); D. HALPERIN, The Merkavah in Rabbinic Literature (New Haven, 1980); M. IDEL, Enoch is Metatron // Immanuel 24-25 (1990) 220-240; L. JACOBS, Jewish Mystical Testimonies (New York, 1977); N. JANOwITZ, The Poetics of Ascent: Theories of Language in a Rabbinic Ascent Text (Albany, 1989); M. Morgan, Sepher Ha-Razim: The Book of Mysteries (Chico, CA, 1983) (TTPS, 11); P. SchÄFER with M. SCHLÜTER and H. G. vON Mutius, Synopse zur Hekhalot-Literatur (Tübingen, 1981) (TSAJ, 2); P. ScHÄFER, The Hidden and Manifest God (Albany, 1992); G. ScHolem, Jewish Gnosticism, Merkabah Mysticism, and Talmudic Tradition (New York, 1965); IDEM, Major Trends in Jewish Mysticism (New York, 1954); M. Swartz, Mystical Prayer in Ancient Judaism: An Analysis of Macaseh Merkavah (Tübingen, 1992) (TSAJ, 28). 
leading pioneers of this approach stand Gershom Scholem and Hugo Odeberg. ${ }^{5}$ Odeberg may well be the first scholar who pointed out that the descriptions of celestial titles for Enoch in 2 Enoch are the most important evidences of possible connections between the apocalypse and texts of the Merkabah tradition.

In these descriptions of celestial titles, one may find the origins of another image of Enoch, quite distinct from early Enoch literature, which was later developed in Merkabah mysticism - the image of the angel Metatron, «The Prince of the Presence». The Slavonic text provides rudimentary descriptions of several traditional Merkabah titles of Enoch-Metatron, (e.g., «the Lad», «the Scribe», «the Prince of the World», «the Prince of the Presence»). ${ }^{6}$ Keeping these manifestations of Merkabah symbolism in mind, this study will focus upon only one of these titles of Enoch, namely, «The Prince or the Governor of the World». The article will also explore some Slavonic terminology related to this title which may yield insight into the origin of the name «Metatron».

The Merkabah tradition stresses the role of Metatron as the «governing power over the nations, kingdoms and rulers on earth». ${ }^{7}$ Sefer Hekhalot pictures Metatron as the Prince of the World, the leader of 72 princes of the kingdom of the world, who speaks (pleads) in favor of the world before the Holy One. Chapter 43 of the short recension of 2 Enoch and a similar passage of the text of 2 Enoch in the Slavonic collection «The Just Balance» ${ }^{8}$ reveal Enoch in his new celestial role. Both texts outline Enoch's instructions to his children, during his brief return to the earth, in which he mentions his new role as the Governor or the Guide of the earth:

And behold my children, I am the Governor of the earth, $p(r)$ ometaya [n( $\rho$ )омет ara], I wrote (them) down. And the whole year I combined and the hours of the day. And the hours I measured: and I wrote down every seed on earth. And I compared every measure and the just balance I measured. ${ }^{9}$

An important aspect of both passages is the Slavonic term n( $\rho$ )омет ara (prometaya), which follows Enoch's title, «The Governor of the World». ${ }^{10}$ This term was deliberately left in its original Slavonic form in order to preserve its authentic phonetic image. Prometaya represents an etymological

${ }^{5}$ Odeberg, 3 Enoch...; Scholem, Major Trends in Jewish Mysticism...; IDEM, Origins of the Kabbalah...

${ }^{6}$ See A. OrLov, «Merkabah Stratum» of the Short Recention of 2 Enoch (M. A. Thesis; Abilene, 1995).

${ }^{7}$ Odeberg, 3 Enoch... 81.

${ }^{8}$ «The Just Balance» (Мерило Праведное) is the Slavonic collection of ethical writings in which the existence of 2 Enoch was made public. See M. Н. Тихомиров, Мерило Праведное по рукописи XIV века (Москва, 1961).

${ }^{9}$ Andersen, 2 Enoch... 217-219.

${ }^{10}$ Andersen translates the title as «the manager of the arrangements on earth». ANDERSEN, 2 Enoch... 217. 
enigma for experts in Slavonic, since it is found solely in the text of 2 Enoch. It should be stressed again that there is no other Slavonic text where the word prometaya is documented.

The prominent Russian linguist I. Sreznevskij, in his Slavonic dictionary, which is still considered by scholars as a primary tool of Slavonic etymology, was unable to provide a definition for prometaya. ${ }^{11}$ He simply put a question mark in the space for the meaning of the word. ${ }^{12}$ The variety of readings for this term in the manuscripts of 2 Enoch $^{13}$ shows similar «linguistic embarrassment» among Slavic scribes who most likely had some difficulties discerning the meaning of this ambiguous term. The readings of other manuscripts include promitaya, prometaemaa, pometaya, pametaa.

One possible explanation for the singular occurrence of prometaya is that the word may actually be a Greek term that was left untranslated in the original text for some unknown reason. In fact, 2 Enoch contains a number of transliterated Hebrew and Greek words preserved in their original phonetic form (e.g., Grigori, Ophanim, Raqia Araboth). But if we investigate the term prometaya more closely, the root meta draws our attention nesessitating further examination of the relationship between the words prometaya and metatron.

Contemporary scholarship does not furnish a consensus concerning the origin of the name «Metatron». In scholarly literature, there are several independent hypotheses about the provenance of the term. I want to draw our attention to one possible interpretation, which could be connected with some materials in 2 Enoch. According to this interpretation, the name «Metatron» may be derived from the Greek word $\mu^{\prime} \varepsilon$ троv (measure, rule). Adolf Jellinek may well be the first scholar who suggested $\mu^{\prime} \varepsilon \tau \rho \circ v$ as an alternative explanation of Metatron, on the assumption that Metatron was identical with Horos. ${ }^{14}$ Gedaliahu Stroumsa in his article, «Forms of God: Some Notes on Metatron and Christ», gives some convincing new reasons for the acceptance of this etymology, on the basis that Metatron not only carried God's name, but also measured Him; he was His Shicur Qomah (the measurement of the Divine Body). ${ }^{15}$ In light of this observation, Stroumsa stresses that «renewed

${ }^{11}$ On the other hand, Vaillant in his edition states that prometaya could be identified as a rare verb corresponding to the Greek $\beta \alpha \sigma \alpha v i \zeta \omega v$. The linguistic source of this suggestion remains unknown. Andersen criticizes this translation, pointing out that the meaning is not quite suitable and does not correspond to earlier materials. See ANDERSEN, 2 Enoch... 217.

12 «промитати, промитага (promitati, promitaja) - ?». И. И. СРезНЕВСКИй, Словарь древнерусского языка (Москва, 1989) Т. 2. 1544.

${ }^{13}$ Andersen stresses that the variations show «theological embarassment» among the Slavic scribes (ANDERSEN, 2 Enoch... 217).

${ }^{14}$ Odeberg, 3 Enoch... 134.

${ }^{15}$ G. G. Stroumsa, Form(s) of God: Some Notes on Metatron and Christ // HTR 76 (1983) 287. 
attention should be given to $\mu^{\prime} \varepsilon$ t $\rho \circ \nu$ and/or metator as a possible etymology of Metatron». ${ }^{16}$

Matthew Black, in his short article devoted to the origin of the name Metatron, expounds upon an additional etymological facet of this interpretation of the name. He traces the origin of the name to a previously unnoticed piece of evidence which can be found in Philo's ${ }^{17}$ Quaest. in Gen., where, among other titles of the Logos, Black finds the term praemetitor. ${ }^{18}$ He further suggests that praemetitor could be traced to the Greek term $\mu \varepsilon \tau \rho \eta \tau$ rís, ${ }^{19}$ the Greek equivalent of the Latin metator, «measurer», applied to the Logos. ${ }^{20}$

The term praemetitor in its hypothetical meaning as a «measurer» is an important piece of evidence because it is almost phonetically identical with the Slavonic term prometaya.

Additionally, the term prometaya is incorporated into the passage which describes Enoch as the Measurer of the Lord. In ch. 43 of 2 Enoch, immediately after the use of this term, Enoch makes the following statement:

I have arranged the whole year. And from the year I calculated the months, and from the months I calculated the days, and from the day I calculated the hours. I have measured ${ }^{21}$ and noted the hours. And I have distinguished every seed on the earth, and every measure ${ }^{22}$ and every righteous scale. I have measured ${ }^{23}$ and recorded them. ${ }^{24}$

A similar passage in the previously mentioned collection, «The Just Balance» also emphasizes the functions of Enoch as the measurer:

And the whole year I combined, and the hours of the day. And the hours I measured: and I wrote down every seed on earth. And I compared every measure and the just balance I measured. And I wrote (them) down, just as the Lord commanded. And in everything I discovered differences. ${ }^{25}$

${ }^{16}$ Stroumsa, Form(s) of God... 287.

${ }^{17}$ The idea that the Metatron figure originally came into Judaism from Philo's Logos speculations was popular in German scholarship of the 19th century. Cf. M. FRIEDLÄNDER, Der vorchristliche Jüdische Gnostizismus (Göttingen, 1898); M. GRÜNBAUM, Gesammelte Aufsätze zur Sprach-und Sagenkunde (Berlin, 1901); M. SACHS, Beiträge zur Sprach-und Alterthums-forschung (Berlin, 1852); N. WeInSteIN, Zur Genesis der Agada (Göttingen, 1901).

${ }^{18}$ M. BLACK, The Origin of the Name Metatron // VT 1 (1951) 218.

${ }^{19}$ Ibid.

${ }^{20}$ Ibid.

${ }^{21}$ измьрих.

22 м\$р8.

${ }^{23}$ измьрих.

${ }^{24}$ ANDERSEN, 2 Enoch... 171.

${ }^{25}$ Ibid. 217. 
These two passages echo the passage from Philo's Quaest. in Gen. which discusses the Divine Logos as the «just measure»:

And «Gomorra», «measure» true and just is the Divine Logos, by which have been measured and are measured all things that are on earth - principles, numbers and proportions in harmony and consonance being included, through which the form and measures of existing things are seen. ${ }^{26}$

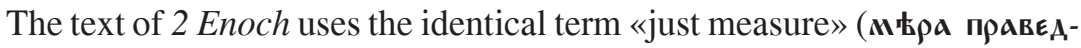
Na), immediately after the passage dedicated to the function of Enoch as a measurer.

In addition to Stroumsa's suggestion about possible connections between «the measurer» and «the measurement of divine body», it is noteworthy that there is another hypothetical link between the functions of Enoch-Metatron as «the measurer» and his «measurement» of human sin for final judgement in the text of 2 Enoch. Following Enoch's introduction as «the measure», the text mentioned the «measurer» of each person for final judgment:

...in the great judgement day every measure and weight in the market will be exposed, and each one will recognize his own measure, and in it he will receive his reward.... Before humankind existed, a place of judgment, ahead of time, was prepared for them, and scales and weights by means of which a person will be tested. ${ }^{27}$

A second possible interpretation of the term prometaya can be traced to Enoch's title, «Governor of the World», after which the Slavonic term prometaya occurs. It can be assumed that prometaya in this situation is a Greek word, which is somehow connected with this title. Possible hypothetical Greek

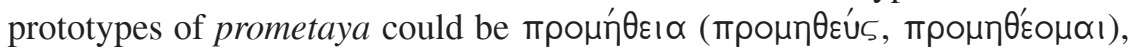
in the sense of protection, care, or providence, which could be directly related to the preceding title of Enoch - the Governor, or the Guide of the earth «I am the Governor of the earth, prometaya, I have written them down».

In conclusion, it is important to note that prometaya could represent a very early, rudimentary form of the title that later was transformed into the term «metatron». In relation to this, Gershom Scholem, in his analysis of the term «metatron», shows that the reduplication of the letter tet (ט) and the ending ron represent a typical pattern that runs through all Merkabah texts. In his opinion, «both the ending and the repetition of the consonant are observable, for instance, in names like Zoharariel and Adiriron». ${ }^{28}$ Further, he stresses that it must also be borne in mind that on and ron may have been fixed and typical constituents of secret names rather than meaningful syllables. ${ }^{29}$

\footnotetext{
${ }^{26}$ Philo, Quaest. in Gen. 4.23.

${ }^{27}$ Andersen, 2 Enoch... 219.

${ }^{28}$ Scholem, Major Trends in Jewish Mysticism... 69

${ }^{29}$ Ibid. 69-70.
} 
Thus, keeping in mind the possible date of 2 Enoch in the first century of the common erabefore the destruction of the Second Temple, prometaya could be one of the earliest traces connecting the names Enoch and Metatron. ${ }^{30}$

\begin{abstract}
The study examines the mysterious Slavonic term prometaya found in 2 Enoch 34 arguing that it could represent a very early, rudimentary form of the name «Metatron»
\end{abstract}

${ }^{30}$ On the hypothetical date of 2 Enoch see: ScHolem, Jewish Gnosticism... 17; Gruenwald, Apocalyptic and Merkavah Mysticism... 50. 